\title{
SYSTEM FOR SIGNALIZATION OF SPEEDING AND LIMITING THE SPEED OF THE INTERNAL TRANSPORT EQUIPMENT
}

\author{
Milan Đorđević ${ }^{1}$, Rodoljub Vujanac, Nenad Miloradović
}

UDC:629.35+656.053.2

DOI: $10.24874 / \mathrm{mvm} .2017 .43 .04 .02$

\begin{abstract}
Modern production requires appropriate logistic approaches to reduce cost and provide better safety conditions during material handling by the forklifts. A forklift can be one of the most dangerous pieces of equipment in the workplace even at lower loads and speeds. The new generation forklifts are equipped with modern control and security systems that make it easier to use. However, older generations of forklifts that do not contain modern control systems are still in use. With lower stability and greater manoeuvrability, combined with uncontrolled traffic areas as well as speed at workplaces, forklifts are involved in many incidents. Even if people are not injured in accidents, there is often damage to buildings, storage systems or stock. This paper describes a safe system that prevents one of the main causes of accidents - speeding. The developed system is related to signalization of speeding as well as to limiting the speed of the electrical forklifts.
\end{abstract}

KEY WORDS: forklift, logistic, internal transport, safety

\section{SISTEM ZA SIGNALIZACIJU PREKORAČENJA BRZINE KAO I NJENO LIMITIRANJE KOD SREDSTAVA UNUTRAŠNJEG TRANSPORTA}

REZIME: Moderna proizvodnja zahteva odgovarajuće logističke pristupe u cilju smanjenja troškova i obezbeđivanje boljih sigurnosnih uslova tokom rukovanja materijalom viljuškarima. Viljuškar može biti jedan od najopasnijih elemenata opreme na radnom mestu čak i pri malim težinama tereta i brzinama. Viljuškari nove generacije su opremljeni savremenim sistemima upravljanja i sigurnosti koji olakšavaju njihovu upotrebu. Međutim, još uvek je jako zastupljena u upotrebi i starija generacija viljuškara koji ne sadrže savremene sisteme upravljanja. Sa smanjenom stabilnošću i većom manevarskom sposobnošću, u kombinaciji sa nekontrolisanim saobraćajnim uslovima, kao i brzinom na radnim mestima, viljuškari su uključeni u veliki broj incidenata. Čak i ako ljudi nisu povređeni u nesrećama, često se oštećuju objekti, sistemi za skladištenje ili materijal. Ovaj rad prikazuje bezbedonosni sistem koji sprečava jedan od glavnih uzroka nesreća, prekoračenje brzine. Razvijeni sistem se odnosi na signalizaciju prekoračenja brzine i ograničavanje brzine električnih viljuškara.

KLJUČNE REČI: viljuškar, logistika, unutrašnji transport, bezbednost

${ }^{1}$ Received October 2017, Accepted November 2017, Available on line first December 2017 
Intentionally blank

Volume 43, Number 4, 2017 


\title{
SYSTEM FOR SIGNALIZATION OF SPEEDING AND LIMITING THE SPEED OF THE INTERNAL TRANSPORT EQUIPMENT
}

\author{
Milan Đorđević ${ }^{1}$, Rodoljub Vujanac ${ }^{2}$, Nenad Miloradović ${ }^{3}$
}

\section{INTRODUCTION}

Internal transport in the strict sense of the word is the transfer of the work items in the production. The transfer of the object is carried out from the warehouse to the production, then within and between production facilities, from the production to the warehouse and within warehouse facilities. Complete internal transport consists of multiple operations such as: loading, transfer, unloading, reloading, where reloading is a combination of loading and unloading of material. Processes of individual, serial or mass production demand the introduction of a suitable method of internal transport, which should be productive, cost-effective, profitable and safe [1]. Efficient and flexible material flow requires appropriate logistic approaches to reduce cost and provide better safety conditions. Growing from individual to serial and from serial to the mass production, increases the degree of mechanization and automatization of transport means. The level of mechanization and automatization of transport means departs from hand trolleys as the least mechanized means used in individual classical production, motorized trolleys, towed trains and forklift trucks (forklifts) to the elevators and conveyors as highly mechanized tools used for modern equipped serial and mass production $[2,3]$.

A forklift is a powerful tool that allows one person to precisely carry, push, pull, lift, stack or tier large heavy loads with little effort. Using a tool such as a forklift, cart or hand truck instead of lifting and carrying items by hand can reduce the risk of suffering a back injury. There is a wide range of forklifts, including pedestrian operated and ride-on forklifts. Forklifts vary in size, ranging from $1 \mathrm{t}$ capacity for general warehouse type work, up to $50 \mathrm{t}$ capacity for shipping container work. They can be powered by batteries, propane, gasoline or diesel fuel.

Approximately 35000 serious injuries and 62000 non-serious injuries involving forklifts occur in the United States every year. OSHA estimates that $11 \%$ of all forklifts are involved in accidents every year [4]. The most common causes of death injuries with a percentage share are shown in Table 1. Even at low speeds, forklifts can cause serious injuries and fatalities. It is not just the forklift operator who can be injured - a forklift or its load can strike pedestrians, too. The human and financial cost of forklift-related incidents for workers, industry and the community is substantial. However, incidents can be prevented, especially when workers and persons conduct a business or work together to improve health and safety outcomes at work through simple and safe practices such as:

\footnotetext{
${ }^{1}$ Milan Djordjevic, Ph. D., prof., The Higher Education Technical School of Professional Studies in Kragujevac, 8 Kosovska Str., 34000 Kragujevac,Serbia,milan.djordjevic@vts.edu.rs

${ }^{2}$ Rodoljub Vujanac, Ph. D., assist. prof., University of Kragujevac, Faculty of Engineering, 6 Sestre Janjić Str., 34000 Kragujevac, Serbia,vujanac@kg.ac.rs

${ }^{3}$ Nenad Miloradovic, Ph. D., assist. prof., University of Kragujevac, Faculty of Engineering, 6 Sestre Janjić Str., 34000 Kragujevac, Serbia,mnenad@kg.ac.rs
} 
- observing speed limits and warning signs,

- wearing correctly fitted seat belts,

- slowing down and

- sounding the horn at an intersection.

Table 1. Causes of fatal injuries by forklift truck handling [4]

\begin{tabular}{|c|c|}
\hline Fatal accident type & Percentage (\%) \\
\hline Crushed by vehicle tipping over & 42 \\
\hline Crushed between vehicle and a surface & 25 \\
\hline Crushed between two vehicles & 11 \\
\hline Struck or run over by a forklift & 10 \\
\hline Struck by falling material & 8 \\
\hline Fall from platform on the forks & 4 \\
\hline
\end{tabular}

The main causes of accidents with forklifts are:

- Lack of operator training,

- Poor maintenance of forklifts.

Modern means of internal transport including forklifts have the capability of software speed limitation. Thus, when entering the production plant or warehouse, the worker presses the button with a maximum speed of $20 \mathrm{~km} / \mathrm{h}$ in the mode of internal operation in which the speed is limited to $5-6 \mathrm{~km} / \mathrm{h}$. The most modern forklifts receive a signal from the transmitter through the doors and automatically switch from fast to slow mode and vice versa. However, older models of forklift trucks that do not have the option of changing modes to limit speed are still in use. The paper presents a technical solution for speed limit that can be installed in any electric forklift. The idea was to develop a safe system of work to control risks and help prevent forklift-related incidents.

\section{PROBLEM IDENTIFICATION AND PROJECT TASK}

\subsection{Problem identification}

The company's management is required to provide secure operating systems, with part of the responsibility being taken over by the supervisors as well as by the operators themselves. Managers or internal inspectors must control the operation of the operator following a number of rules. The most important rule is the respect for the predicted speed. The procedures stipulate that the speed of the vehicle must be adjusted in accordance with the characteristics of the roads, the type of goods being transported, and the possibility of stopping the vehicle. Speed is particularly limited near intersections, in curves, on slopes, on slippery surfaces, in cases of low visibility, narrow passages, etc.

Maximum speed has been limited as following:

- At the open space, it is limited to $10 \mathrm{~km} / \mathrm{h}$ in unloaded condition or up to $5 \mathrm{~km} / \mathrm{h}$ in loaded condition. 
- At the enclosed space, regardless of whether the forklift is empty or loaded, it is limited to $5 \mathrm{~km} / \mathrm{h}$.

These speeds are maximum allowed, but this does not mean that they can always be achieved. When driving conditions require it, a lower driving speed is appropriate for safe driving. Speed limit signs are placed along the logistics corridors. Although the speed limit signs are placed on all roads within the factory, Figure 1, it was noticed that drivers often did not respect the limits that are prescribed.

Firstly, a retraining of the drivers must be done and a checklist of safe handling of logistic equipment must be printed for all logistic equipment, Figure 1.

\section{Operator's Daily Checklist: Electric Forklift}

Check aach ilem balore the shit star ts Put a check in the box it th e item is OK.

Explair any unchecked iems a: the bot:cm a-d report them to a supervisor

Do not use an ursate forklift! Your safety is at risk.

Forklift Scrial Numbor:

\begin{tabular}{|c|c|}
\hline \multicolumn{2}{|c|}{ Operator: } \\
\hline \multicolumn{2}{|c|}{ Hou-Meter Reading: } \\
\hline$\sqrt{ }$ & Visual Check \\
\hline & Tires are inflated and tree cl exressive wear cr damage Nuls are 5 ofht \\
\hline & Forks and rrast are nol bent, som, or cracked. \\
\hline & Lead bow rest cktens on $\mathrm{s}$ in slace and not bert, sracked, er lacee. \\
\hline & 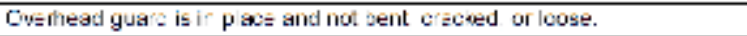 \\
\hline & At:c"mene sif cquipeced) cperate OK an: are not damaged. \\
\hline & Fonklift hedty is f-ee of exressive int, greme, sc cil \\
\hline & Hyoraulis oil is f, $\|$ als fres of kaks. \\
\hline & Battery connert ons are tight \\
\hline & 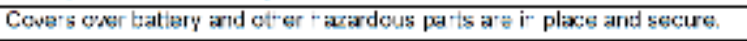 \\
\hline & I sad rat my plate is sresent an: reatcahle \\
\hline & 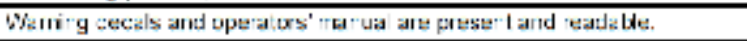 \\
\hline & Scat bett or c straint is acos ssible ar d not sarraged. sily. or d rty. \\
\hline & 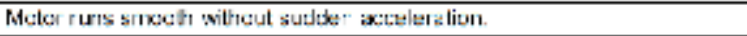 \\
\hline & Horn norks. \\
\hline & Turn si-nal cif equipend! aperates snonthly \\
\hline & L gints (-cad, tail and waming! work anz ars airned cerrectly. \\
\hline & Gauges a-di-struments are unrking \\
\hline & Lft and loyer be eratss smact-ly with zut exoses drift. \\
\hline & Tilt ope ates smo-thy wtho t excessive drift or 'chate"' \\
\hline & Control levers ars lakeled not lecse o- bi" d"g and "reesly return to ne. fra \\
\hline & 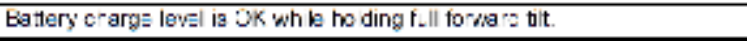 \\
\hline & Steeri-g is amooth and reepongivg, firee o' excessive play. \\
\hline & Brakes work ard funch sn smocthly :sthout grabeng. No 1.id leaks. \\
\hline & Park g crake w thas the bork ft zn a ir cline. \\
\hline & Bajup alern (l+́ equ cped) nork.s. \\
\hline & \\
\hline & \\
\hline & \\
\hline & \\
\hline
\end{tabular}

Figure 1. Operator's daily checklist: electric forklift 
The next step is to introduce driver control by placing markings on vehicle wheels, Figure 3, through which excessive speed could be detected. When the driver exceeds the speed of $5 \mathrm{~km} / \mathrm{h}$, the observer on the side could observe an overrun, since at $120 \mathrm{rpm}$ there is a "wagon-wheel" effect when the wheel seems to stand in place. Two basic problems with this system are:

- The observer (inspector) must be close to the side of the vehicle, in order to note the effect;

- The effect is achieved at a rotation speed of $120 \mathrm{rpm}$, which, for the wheel radius of $15 \mathrm{~cm}$, amounts to $6 \mathrm{~km} / \mathrm{h}$. For vehicles with wheels radii of $25 \mathrm{~cm}$, the same effect is achieved at a speed of $11 \mathrm{~km} / \mathrm{h}$.

- The driver has no insight into his speed.

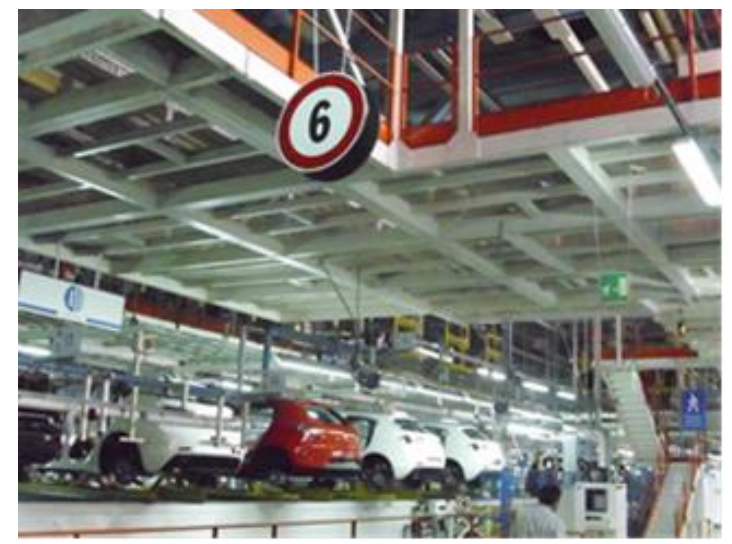

Figure 2. Sign of speed limit within production lines

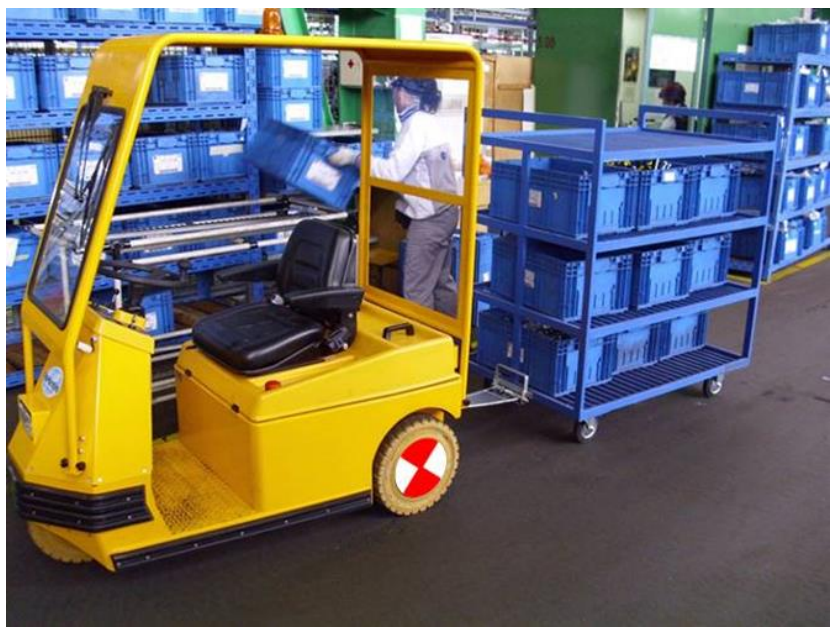

Figure 3. Speed observation over the mark on the wheel

All of these above mentioned problems were sufficient reason to approach the development of a system that will be able to signal when the operator operating the forklift 
exceeds the allowed speed over $5 \mathrm{~km} / \mathrm{h}$ and the possibility of automatic limitation to 10 $\mathrm{km} / \mathrm{h}$.

\subsection{Project task}

Since internal logistics has a variety of transport systems, it was necessary to design and implement a system that would cover the entire factory fleet. The set up requests were:

- $\quad$ Precise speed measurement (most available transport systems did not have this).

- The sound signalization should warn the driver that he exceeded the speed of 5 $\mathrm{km} / \mathrm{h}$.

- Light signalization - a yellow rotary light that would be noticeable at a distance of $200 \mathrm{~m}$ and which would alert pedestrians in the vicinity of a vehicle moving at a speed higher than permitted. In addition, internal inspectors would be able to spot a vehicle moving at a speed higher than permitted from a long distance.

- Physically limit the speed up to $10 \mathrm{~km} / \mathrm{h}$. Vehicles could travel at speeds over 20 $\mathrm{km} / \mathrm{h}$.

\section{DESCRIPTION OF A NEW SYSTEM}

The system is designed to set 6 neodymium magnets on the hub of wheel which will rotate together with the hub of wheel [5]. When wheel rotates, the magnets pass at about $5 \mathrm{~mm}$ of distance from the fixed magnetic encoder - reed relay, Figure 4 . Each time when a magnet passes near the magnetic encoder, an impulse is induced and sent to the electronic module for speed limit and signalling (EMSLS) where the impulses are added. The schematic layout of the system is shown in Figure 5.

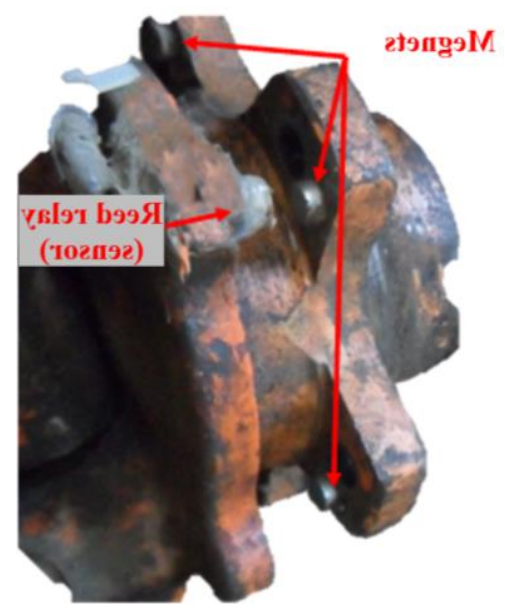

Figure 4. The wheel hub with magnets and magnetic encoder 


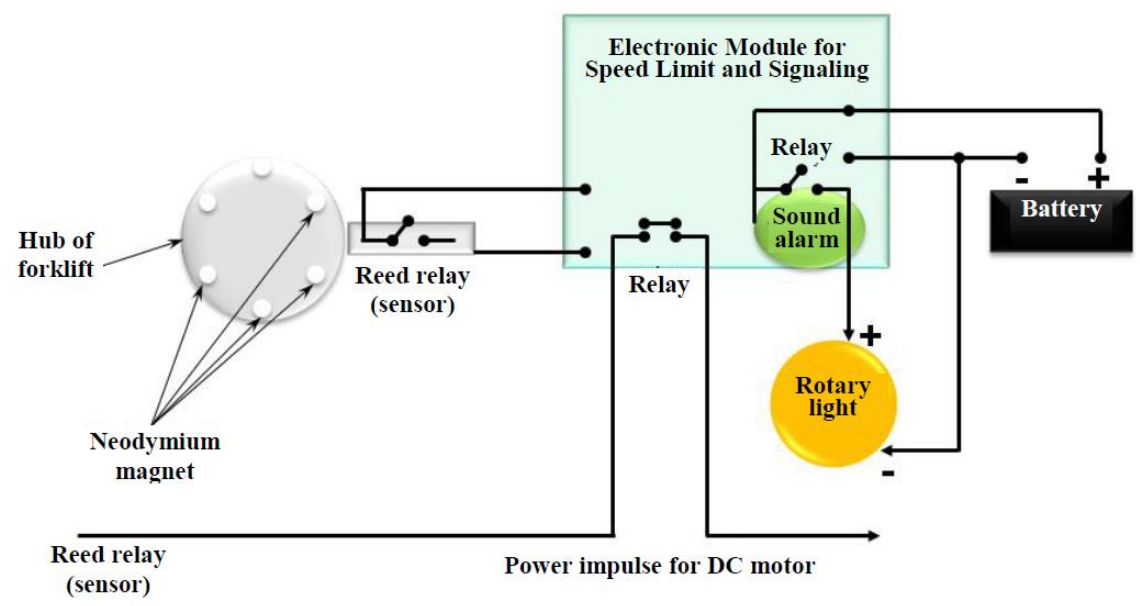

Figure 5. Schematic layout of the system

EMSLS (which contains ATMEL microcontroller C8051) is programmed for each type of vehicle, taking into account the dynamic radius of the tire (important for precise measurement of the speed of the vehicle). Through the number of pulses and a time base for a specified range of tires, the speed can be generated, with measurement error below $10 \%$ (meets strict requirements). An external programmer programs each microcontroller. The hysteresis loop for „cut off / cut in“ DC power impulse (written in assembler) provided fine or "soft" crossings from „,cut in" to „cut off" conditions. This means that the driver would not feel sudden vibrations when breaking the motor.

Based on the measured speed, EMSLS decides which action to take. If a speed of 6 $\mathrm{km} / \mathrm{h}$ is reached, a $72 \mathrm{~dB}$ sound alarm (piezo buzzer) is activated, signalling the driver of the vehicle that the programmed limit is exceeded $(5 \mathrm{~km} / \mathrm{h})$. In addition, the light signalization, yellow rotary light, Figure 6, is included, which warns all persons near the vehicle that there is a potential danger. That is a signal to the competent inspectors that the driver has exceeded the permissible speed.

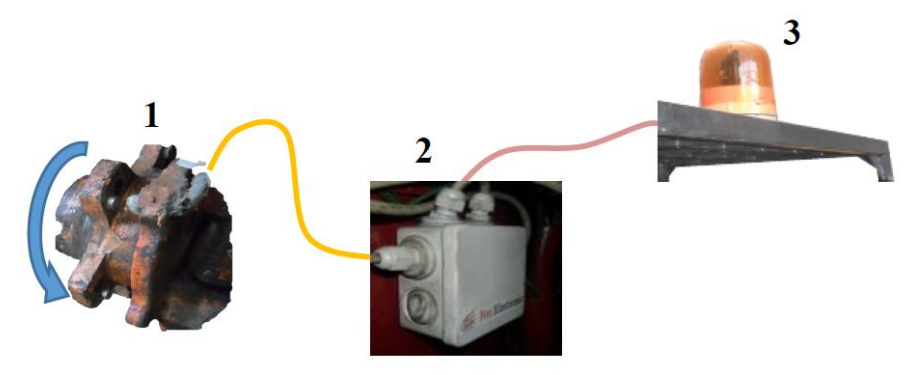

Figure 6. Basic parts of the system: 1. The wheel hub with magnets and reed relay (sensor), 2. EMSLS (Electronic Module for Speed Limit and Signalling), 3. Rotary light

The EMSLS will give a signal to switch-off the drive when the operator reaches the second speed limit with the vehicle (in this case $-10 \mathrm{~km} / \mathrm{h}$ ). For electric forklifts, the speed is limited by the break of the current drive to the DC motor using the NC relay in the 
electronic module, while in the case of gas forklifts, the speed is limited by the interruption of the fuel supply (reprogramming the ECU of the newer generation).

\section{CONCLUSIONS}

Manually operated forklifts are widely used in the implementation of transhipment - storage and other processes in intralogistics today. However, constant demands for the increase of efficiency, reliability and security of logistics processes in this area imply the research and implementation of new solutions. One of the directions of the research is the application of modern solutions in the field of IT, which significantly provides the preconditions for increasing productivity and security. Clearly, this approach has some disadvantages - it requires additional investments in equipping forklifts as well as additional employee training. The most important advantage of the described system for signalization of speeding and speed limitation is the improvement of safety conditions for operation. After the introduction of this system, no injuries were found in which the causative agent was a logistical means of transport. In addition, savings of $18 \%$ in energy consumption are used to start the engine of transport vehicles, which, in addition to economically positive results, also reflects the social responsibility of the company that contributes positively to the environment.

\section{ACKNOWLEDGMENT}

The paper is a part of the research done within the project TR32036 supported by the Ministry of Education, Science and Technological Development of the Republic of Serbia.

\section{REFERENCES}

[1] Vujanac, R., Disic, A., Djordjevic, M.: Low cost automated system for heavy containers handling, Faculty of Mechanical Engineering Belgrade, Proceedings of the XXI International Conference MHCL'15, pp. 189-192, 2015.

[2] Vujanac R., Djordjevic M., Miloradovic N.: Mechanical Tugger Trains System for Internal Material Handling, The Sixth International Conference Transport and Logistic til 2017, Nis, pp. 73-76, 2017.

[3] Vujanac R.: Semi-Automatic Mechanical Transport-Manipulation System for Production and Assembly Lines, Invention, Response number 2015/5879, Belgrade, 2016.

[4] Washington State Department of Labor \& Industries, Division of Occupational Safety and Health: Forklift Safety Guide, Publication F417-031-000, 2015.

[5] Djordjevic, M., Jovanovic, S.: System for Signalization of Speeding as well as Limiting the Speed of the Internal Transport Equipment, Project developed by company FOX Electronics, 2011. 